\title{
Analyst Optimistic Forecasting and Impression Management of CSR Disclosure - Empirical evidence from China
}

\author{
Kang Fengzhuo ${ }^{1}$, Chen Haoran ${ }^{2 *}$ \\ ${ }^{1}$ Business School of Henan University, kaifeng, Henan, China \\ ${ }^{2}$ Finance Department of Kaifeng University, kaifeng, Henan, China
}

\begin{abstract}
Taking the data of Shanghai and Shenzhen A-share listed companies from 2010 to 2019 as samples, this paper finds that there is A "pressure-promoting" effect of analysts' optimistic predictions on impression management of CSR information disclosure. Further research shows that, compared with the enterprises with better performance, the "pressure promotion" effect of analysts' optimistic prediction is more significant for enterprises with poor performance. Compared with enterprises without third-party assurance, the third-party assurance enterprises are less affected by the "pressure promotion" effect predicted by analysts. Compared with mandatory disclosure of CSR reporting companies, companies that voluntarily disclose CSR reports are less affected by the "pressure promotion" effect predicted by analysts optimistic. After a series of robustness tests, the above conclusions are still valid.
\end{abstract}

\section{Introduction}

Impression management of CSR information disclosure mainly refers to the management's whitewash or cover up of CSR information disclosure, such as "reporting good news but not bad news", exaggerating or falsely reporting the performance of corporate social responsibility, so as to create a good image of the enterprise 1. CSR's disclosure of impression management distorts the value of information and is not consistent with the original intention of reducing information asymmetry. If left unchecked, it will lead to adverse consequences, such as "bad money drives out good money" and the spread of junk information. Therefore, it is urgent to identify the motivation, causes and strength of impression management of CSR disclosure, and strengthen the regulation and supervision of CSR information disclosure.

As an important information intermediary in the capital market, analysts play an important role in alleviating the information asymmetry between enterprises and investors. However, analysts' research reports often show optimistic forecasts and blind followup behavior, which will bring excessive short-term pressure to managers. Existing studies have confirmed that this kind of pressure will lead managers to myopia and induce managers' self-interested behavior, which is typically manifested as the enhancement of management's motivation for information manipulation 23. This gives rise to a realistic question worthy of consideration. Do analysts' optimistic predictions have a "pressurepromoting" effect on impression management in CSR information disclosure? Unfortunately, there is little literature examining the economic consequences of analysts' optimistic forecasts from the perspective of non- financial information about firms. Therefore, based on the perspective of analysts' optimistic prediction, this paper takes CSR information disclosure impression management as the research object, and investigates the impact of analysts' optimistic prediction on CSR information disclosure impression management.

The research of this paper has certain theoretical and practical significance. First of all, this paper expands the research field of influencing factors of CSR information disclosure impression management, enriches the relevant research on analysts' optimistic prediction of economic consequences, and in practice, this paper has reference significance for improving the quality of corporate social responsibility information disclosure and investor protection, In addition, this paper also provides experience reference for corporate social responsibility information regulatory agencies.

\section{Theoretical analysis and hypothesis proposed}

Based on the "stress hypothesis" of analyst tracking, analysts set an image benchmark for the enterprises after they release research reports on the enterprises concerned. This kind of invisible pressure will induce the management to manipulate information disclosure through covert means to meet analysts' expectations. As a result, the more optimistic analysts' forecasts are, the more pressure management will face. A large number of studies have confirmed that analysts will focus on and analyze CSR information of enterprises, and play an important role in the process of transferring CSR information value to information users 45 . Therefore, from the perspective of

*Corresponding author:13676940093@126.com 
the enterprise, after being followed by analysts, the enterprise management will pay more attention to the disclosure of CSR information, and the more optimistic the analysts predict, the greater the pressure the management will face, and the possibility that the management will build a good image of the enterprise through impression management of CSR information disclosure will also increase. Based on this, this paper proposes hypothesis 1 .

H1: Analysts' optimistic predictions have a "pressurepromoting" effect on impression management of CSR information disclosure.

\section{Research design}

\subsection{Data sources}

Taking Shanghai and Shenzhen A-share listed companies from 2010 to 2019 as samples, this paper selects the CSR score data of Hexun. Analysts' optimistic forecast data and other variable data are from CSMAR and Wind databases. After eliminating the samples of ST and *ST, finance and insurance, and missing key variables, 6892 sample data are finally obtained. In order to overcome the influence of extreme values, all continuous variables are processed with $1 \%$ winsorize tail reduction.

\subsection{Variable definition}

\subsubsection{CSR information disclosure impression management degree}

Referring to the existing literature678, this paper constructs model (1). In model (1), the total score of CSR is taken as the explained variable, and the relevant control variables are explained as follows, among which the enterprise size (Size), asset liability ratio (Lev), total asset net interest rate (ROA) and equity to market ratio (MTB) reflect the basic financial characteristics of enterprises; management shareholding ratio (Mhold), institutional shareholding ratio (Ihold) and executive compensation (Pay) reflect the level of corporate governance; place of incorporation (Place), listing location (List) and external audit (Big4) reflect the external environment of enterprises. Finally, this paper regards the positive residual value of regression estimation of model (1) as the proxy variable of CSR information disclosure impression management degree, and the symbol is CSR_e.

$$
\begin{aligned}
\text { CSR_t }_{\mathrm{i}, \mathrm{t}}= & \beta_{0}+\beta_{1} \text { Size }_{\mathrm{i}, \mathrm{t}}+\beta_{2} \text { Lev }_{\mathrm{i}, \mathrm{t}}+\beta_{3} \text { ROA }_{\mathrm{i}, \mathrm{t}} \\
& +\beta_{4} \text { MTB }_{\mathrm{i}, \mathrm{t}}+\beta_{5} \text { Mhold }_{\mathrm{i}, \mathrm{t}}+\beta_{6} \text { Ihold }_{\mathrm{i}, \mathrm{t}} \\
& +\beta_{7} \text { Pay }_{\mathrm{i}, \mathrm{t}}+\beta_{8} \text { Place }_{\mathrm{i}, \mathrm{t}}+\beta_{9} \text { List }_{\mathrm{i}, \mathrm{t}} \\
& +\beta_{10} \text { Big }_{\mathrm{i}, \mathrm{t}}+\xi_{\mathrm{i}, \mathrm{t}}
\end{aligned}
$$

\subsubsection{Analysts' optimistic forecast}

In this paper, we learn from M.D.Ma9 measurement of analysts' optimistic forecast indicators, and measures them by the optimistic forecast based on earnings forecast. The specific calculation method is shown in formula (2).

$$
O P T_{-} F_{\mathrm{i}, \mathrm{t}}=\frac{O p t_{i, t}}{A l l_{i, t}}
$$

In formula (2), $O p t_{i, t}$ represents the number of earnings forecast deviations greater than $0, A l l_{i, t}$ represents the total number of earnings forecasts.

\subsection{Model design}

In order to test the impact of analysts' optimistic forecasts on CSR information disclosure impression management, this paper constructs model (3) to test hypothesis 1 .

$$
\begin{aligned}
C S R_{-} e_{\mathrm{i}, \mathrm{t}} & =\beta_{0}+\beta_{1} O P T_{-} F_{\mathrm{i}, \mathrm{t}} \\
& +\beta_{\mathrm{j}} \text { Controls }+ \text { Industry _FE } \\
& + \text { Year_FE }+\xi_{\mathrm{i}, \mathrm{t}}
\end{aligned}
$$

The control variables in model (3) are simplified by the symbol Controls, which are the same as those in model (1).

\section{Result analysis}

Table 1 shows that the regression coefficients of OPT_F is significantly positive at the $1 \%$ level, indicating that analysts' optimistic forecasts have a "pressure promoting" effect on CSR information disclosure impression management. Hypothesis 1 is verified.

Table1. Test results of hypothesis 1

\begin{tabular}{|c|c|c|}
\hline \multirow{2}{*}{ VARIABLES } & \multicolumn{2}{|c|}{ Dependent variable:CSR_e } \\
\cline { 2 - 3 } & $(\mathbf{1})$ & $(\mathbf{2})$ \\
\hline OPT_F & $0.1055^{* * *}$ & $0.1055^{* * *}$ \\
\hline & $(5.55)$ & $(3.81)$ \\
\hline Controls & Yes & Yes \\
\hline Industry_FE & Yes & Yes \\
\hline Year_FE & Yes & Yes \\
\hline Company_FE & - & Yes \\
\hline $\mathrm{N}$ & 6892 & 6892 \\
\hline $\mathrm{r} 2$ a & 0.284 & 0.283 \\
\hline $\mathrm{F}$ & 145.13 & 61.32 \\
\hline
\end{tabular}

Note: $\mathrm{T}$ values in brackets, $* * *, * *$, and $*$ represent significant differences at $1 \%, 5 \%$, and $10 \%$ levels. Company_FE is the cluster test of controlling enterprise. 


\section{Further study}

\subsection{Research on the heterogeneity of enterprise performance}

Based on the "stress hypothesis" of analyst tracking, the degree of stress on the management of enterprises caused by analysts' optimistic prediction should be heterogeneous under different performance of enterprises. Based on the median of total assets net profit margin (ROA) of the sample enterprises, this paper divides the enterprises into two groups: "good performance" and "poor performance", and makes group regression. The (1) and (2) columns of table 2 show that in the "good performance" group, the indicator of analysts' optimistic forecast is not significantly correlated with CSR_e coefficient, but in the "poor performance" group, the indicator of analysts' optimistic forecast is significantly positively correlated with CSR_e. It shows that when the enterprise's own performance is good, it is easier to reach the analysts' optimistic expectations, then the analysts' optimistic forecasts have less pressure on the enterprise management, and the enterprise managers have less impression management on CSR information disclosure. However, when the performance of the enterprise is poor, the sensitivity of the enterprise management to the optimistic forecast of the analysts will increase, and the degree of impression management of the enterprise management on the CSR information disclosure will also be greater.

\subsection{Research on the heterogeneity of voluntary and compulsory disclosure of CSR reports}

At present, China's CSR information disclosure presents a "dualistic situation" in which voluntary disclosure and mandatory disclosure coexist. Considering this special institutional background, this paper further divides the sample into voluntary disclosure group and mandatory disclosure group for grouping regression. The (3) column in table 2 is the regression results of voluntary disclosure group, The coefficients of OPT F and CSR e is not significant. The (4) column is the regression results of mandatory disclosure group, and the coefficients of OPT F and CSR e was significantly positive at the level of $1 \overline{\%}$. It shows that compared with the enterprises that voluntarily disclose CSR reports, the capital market and the regulatory authorities pay more attention to the enterprises that compulsively disclose CSR reports, which leads to greater pressure on them and makes them more likely to use the impression management of social responsibility disclosure as a tool to seek private interests.

\subsection{Research on the heterogeneity of whether CSR reports are verified by the third party}

At present, China Securities Regulatory Commission, Shanghai Stock Exchange and Shenzhen stock exchange not only encourage enterprises to voluntarily disclose social responsibility reports, but also encourage enterprises to disclose social responsibility assurance reports. Is there any difference in the "pressure promotion" effect of analysts' optimistic prediction between the authenticated and unauthenticated firms? According to whether the CSR report has been authenticated by a third-party authority, this paper divides the sample into authentication group and non authentication group for grouping regression. It can be seen the results from the (5) and (6) columns of table 2, the regression coefficient is significantly positive only in the non assurance group, but not in the assurance group. Therefore, the self-interest tendency of the management of the enterprises identified by the third-party professional assurance agencies has been restricted, and the impression management behavior of CSR information disclosure has also been effectively suppressed.

Table2. Results of heterogeneity analysis

\begin{tabular}{|c|c|c|c|c|c|c|}
\hline \multirow{3}{*}{ VARIABLES } & \multicolumn{6}{|c|}{ Dependent variable:CSR_e } \\
\hline & (1) & (2) & (3) & (4) & (5) & (6) \\
\hline & Better performance & Poor performance & Voluntary & Compulsory & Authenticated & Unauthenticated \\
\hline$O P T F$ & -0.0083 & $0.2922 *$ & 0.0352 & $0.1189 * * *$ & 0.0305 & $0.1231 * * *$ \\
\hline & $(-0.04)$ & $(1.75)$ & $(1.61)$ & $(3.69)$ & $(1.39)$ & $(5.72)$ \\
\hline Industry_FE & Yes & Yes & Yes & Yes & Yes & Yes \\
\hline Year FE & Yes & Yes & Yes & Yes & Yes & Yes \\
\hline Controls & Yes & Yes & Yes & Yes & Yes & Yes \\
\hline $\mathrm{N}$ & 3446 & 3446 & 5121 & 1771 & 190 & 6702 \\
\hline r2 a & 0.292 & 0.265 & 0.292 & 0.247 & 0.301 & 0.269 \\
\hline $\mathrm{F}$ & 99.75 & 52.88 & 73.21 & 90.30 & 96.25 & 53.21 \\
\hline
\end{tabular}

Note: T values in brackets; ${ }^{* * *}, * *$, and * represent significant differences at $1 \%, 5 \%$, and $10 \%$ levels, respectively.

\section{Robustness check}

In order to further ensure the robustness of the research conclusions, the following methods are adopted to test the robustness: first, change the indicator measure of analysts' optimistic prediction; learn from the research of M.D.Ma9, the proportion of the number of stocks rated as "buy" in the number of all stock ratings is taken as the proxy indicator of optimistic prediction, and the symbol is OPT_R; second, change the index measurement of CSR information disclosure impression management degree, the total score of CSR in model (1) was replaced by $\ln (\mathrm{CSR}) \mathrm{T}+1)$ (natural logarithm of CSR total score), CSR_code (10 grades according to the total score of CSR, $0-10$ scores are recorded as 1 , and so on, forming a 
discrete variable of 10 grades system), and re estimate the regression of model (1) to get the corresponding positive residual value CSR_e1 and CSR_e2, and then retest hypothesis 1 . The test results in table 3 show that the main conclusions of this paper have not changed.

\begin{tabular}{|c|c|c|c|}
\hline \multicolumn{2}{|r|}{ Table3. } & \multicolumn{2}{|l|}{ Robustness test } \\
\hline $\begin{array}{c}\text { VARIABL } \\
\text { ES }\end{array}$ & $\begin{array}{c}(1) \\
\text { Dependent } \\
\text { variable:CS } \\
R_{\mathrm{R}} \mathrm{e}\end{array}$ & $\begin{array}{c}(2) \\
\text { Dependent } \\
\text { variable:CSR } \\
\text { e1 }\end{array}$ & $\begin{array}{c}(3) \\
\text { Dependent } \\
\text { variableCSR } \\
\text { e2 }\end{array}$ \\
\hline OPT R & $0.1005^{* * *}$ & & \\
\hline & $(5.54)$ & & \\
\hline OPT_R & & $0.0710 * *$ & $0.0521 * *$ \\
\hline & & $(2.50)$ & $(2.49)$ \\
\hline $\begin{array}{c}\text { Industry_ } \\
F E\end{array}$ & Yes & Yes & Yes \\
\hline Year_FE & Yes & Yes & Yes \\
\hline Controls & Yes & Yes & Yes \\
\hline $\mathrm{N}$ & 6892 & 6892 & 6892 \\
\hline $\mathrm{r} 2 \_\mathrm{a}$ & 0.312 & 0.296 & 0.281 \\
\hline $\mathrm{F}$ & 150.2 & 121.1 & 136.0 \\
\hline
\end{tabular}

Note: $\mathrm{T}$ values in brackets; $* * *, * *$, and $*$ represent significant differences at $1 \%, 5 \%$, and $10 \%$ levels respectively.

\section{Conclusion and enlightenment}

Combined with the actual situation of CSR information disclosure in China's capital market environment, this study verifies that analysts' optimistic prediction has a negative effect of "pressure promotion" on impression management of CSR information disclosure. Further research finds that enterprises with poor performance, compulsory disclosure of CSR reports and without thirdparty verification are more affected by analysts' optimistic prediction, and the degree of impression management of CSR information disclosure is also stronger. After a series of robustness tests, the above conclusion still holds.

According to the conclusions of this study, this paper puts forward the following policy recommendations: (1) improve the prevention mechanism of analysts' optimistic forecast deviation, give full play to the role of analysts' reputation mechanism; (2) regulators need to strengthen the examination of the authenticity of CSR information disclosure, encourage enterprises to conduct independent third-party authentication on CSR reports, and focus on the enterprises with poor performance and compulsory supervision; (3) investors should be cautious about analysts' forecast results, especially the impression management of non-financial information disclosure under the pressure of analysts' optimistic forecast.

\section{References}

1. M. L. Sung. "On impression management in information disclosure of listed companies". J. Accounting Research, 3(2004): 40-45.

2. S. X. Hung, P. Pereira, C. Wang. "Analyst Coverage and the Likelihood of Meeting or Beating Analyst Earnings Forecasts". J. Contemporary Accounting Research, 34, 2(2017).
3. C. T. Li, Y. Zhao, X. Xu, "Press the gourd to float the ladle: Analysts' tracking and earnings management". J. Financial research, 4(2016): 144-157.

4. W. J. Hu, L. R. Han, Raynolde, C. Wang. "Analyst attention, institutional shareholding ratio and accounting information disclosure -- regression analysis based on continuous logit model".J. Research on financial problems, 6(2016): 90-101.

5. L. L. Cheng, Y. S. Wang, X. Xu. "Securities analyst tracking and corporate social responsibility information disclosure- Based on China's capital market”. J. Macroeconomic Research, 5(2014):107116.

6. Y. X. Huang, Z. Yao.”Corporate social responsibility report, impression management and corporate performance" .J. Economic management, 38, 1(2016): 105-115.

7. L. Song, J. L. Wang, S. J. Yao. "Influencing factors of social responsibility information disclosure in annual reports of listed companies". J. Economic management, 34, 2(2012): 40-49.

8. Z. Y. Zhang, J. T. Qiu.”Accounting conservatism, corporate governance and impression management of Social Responsibility Report”. J. Financial theory and Practice, 38, 3(2017): 77-83.

9. M. D. Ma, Y. T. Wang, J. X. Wang. "The mystery of negative information disclosure and analysts' optimistic prediction: information decision or economic benefits?". J. Economic management , 42, 9(2020): 144-159. 